\title{
石油中の非炭化 水素成分
}

\author{
冨 永 博 夫*
}

Non-hydrocarbon Constituents in Petroleum.

Hiroo Tominaga*

\section{I. まえがき}

いうまでもなく石油は各種の炭化水素の混合物である が, 炭化水素以外に, イオウ, 窒素, 酸素, 各種金属な ぞの有機化合物をかなり多量に含んでいる。イオウ化合 物を例にとれば，原油中のイオウ元素換算の含有量は少 ないもので $0.1 \%$ ，多いものは $5 \%$ こえる。いまイオ ウ化合物 1 分子あたりイオウ原子が 1 個含まれ，またイ オウ化合物の平均分子量が炭化水素のそれに等しく 240 と仮定すれば，イオウ元素としての $1 \mathrm{wt} \%$ はイオウ化 合物としては $7.5 \mathrm{wt} \%$ に相当する。このようにみると， 石油中のイオウ化合物の存在量は軽視し得ないものであ ることが知られる。窒素, 酸素, 金属等の原油中の含有 量はそれぞれおよそ $0.5 \mathrm{wt} \%$ 以下であり，イオウに較 べれば少ないとはいえ，化合物の形での含有量は決して 無視できない。

原油の非炭化水素成分の含有量は油層の属する地質年 代, 地球化学的, 物理的環境に左右され, また原油の比 重，基種 (ベース)**等によって変化するが，図 1 は北 米カリフオルニヤ産の Wilmington 原油についての 1 例を示したものである。この場合, 非炭化水素成分の含 有量はおよそ $50 \%$ にもおよび，重質留分はそのほとん どが非炭化水素からなることが知られる。

このようなわけで，石油の起源に関する研究，石油精 製法や石油製品の品質改良研究において，石油の非炭化 水素成分に関する知識は不可欠であるといっても過言で はないであろら。とくに近年，世界的に，非炭化水素成 分含有量の多い重質原油の開発が相次ぎ，その原油市場

* 東京大学工学部合成化学科

* Department of Synthetic Chemistry, Faculty of Engineering, University of Tokyo

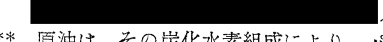

** 原油は，その炭化水素組成により，パラフィン基，混合基(むるいは 中間基), ナフテン基等に分類される。

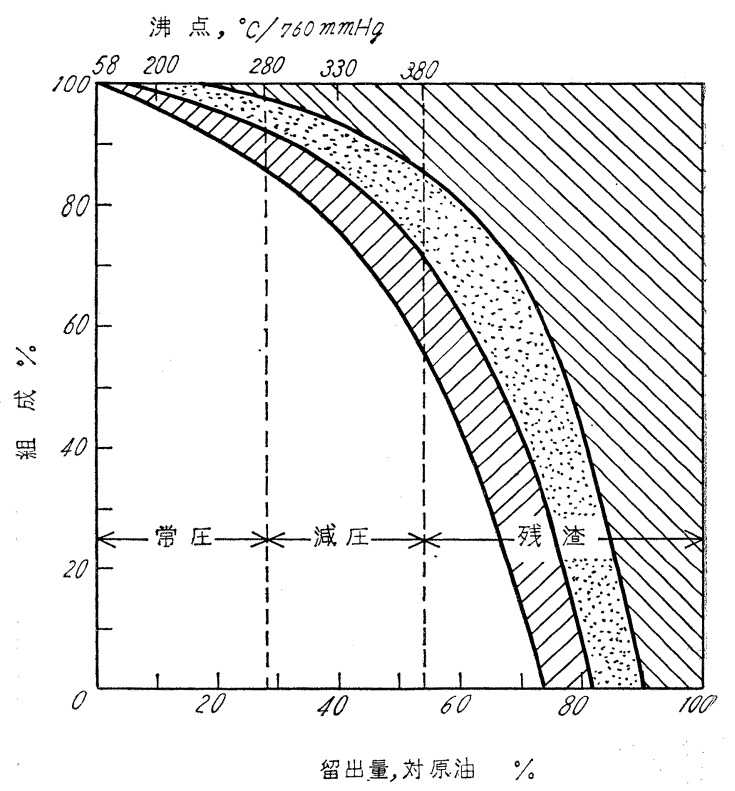

図 1 Wilmington 原油中の非炭化水素成分 $(\mathrm{S}: 1.59, \mathrm{~N}: 0.65, \mathrm{O}: 0.44 \mathrm{wt} \%)$
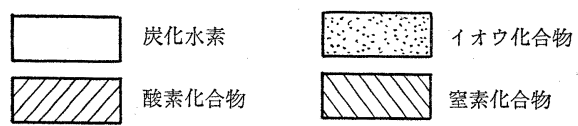

におけるシェアが高まっている。他方，石油製品の品質 高度化の要求から, 水素化分解によるガソリン, 灯軽油 等の製造, 潤滑油の水素化精製, 重油の直接脱硫等のプ ロセスが開発ないし工業化されつつある。したがって， 従来ほとんど知られていなかった重質石油留分の非炭化 水素組成についての研究が広汎かつ精力的に進められる ようになった。最近の物理化学的手法による機器分析の 進歩がこの研究の推進に大きな寄与をなしていることは もちろんである。

この稿では, 石油中の各種非炭化水素のタイプ別 分 
表 2 数種の原油のイオウ化合物のタイプ分析

(全イオウに対する\%)

\begin{tabular}{l|l|r|r|r|r|r|r|r|r}
\hline \multicolumn{1}{c|}{ 原 油 } & \multicolumn{1}{|c|}{ 産 地 } & 全イオウ & 元 素 S & \multicolumn{1}{|c|}{$\mathrm{H}_{2} \mathrm{~S}$} & $\mathrm{RSH}$ & $\mathrm{RSSR}$ & $\mathrm{RSR}$ (I) & RSR (II) & 残查イオウ \\
\hline Wasson & Tex. (USA) & 1.85 & 0.1 & 0.0 & 15.3 & 7.4 & 11.6 & 13.0 & 52.6 \\
Deep River & Mich. (USA) & 0.58 & 0.0 & 0.0 & 45.9 & 22.5 & 0.0 & 3.0 & 28.6 \\
Velma & Okla. (USA) & 1.36 & 0.4 & 0.0 & 1.1 & 0.7 & 12.4 & 41.5 & 43.9 \\
Agha Jari & (イラン) & 1.36 & 0.0 & 0.0 & 8.5 & 3.4 & 12.8 & 9.6 & 65.7 \\
Kirkuk & (イラク) & 1.93 & 0.0 & 0.0 & 7.9 & 5.5 & 20.9 & 24.7 & 41.0 \\
\hline
\end{tabular}

上の分析法の詳細は原報にゆずり，この方法による分

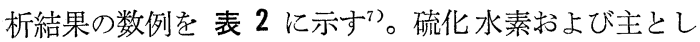
てその酸化生成物と考えられる元素イオウの含有量は一 般に僅少である。内容の不明な残查イオウ（主として重 質留分に偏在する。多環縮合チオフェン類と考えられて (るる）の比率が多い。以上を除くと，メルカプタンの多 WDeep River 原油と，硫化物の多い Velma 原油, Kirkuk 原油が対照的である*。

図 3 は北米テキサス産の Wasson 原油の沸点別, イ オウ化合物分布を示したものである ${ }^{1)}$ 。低 沸点のガソリ ン留分ではメルカプタンイオウが主であり，灯・軽油留

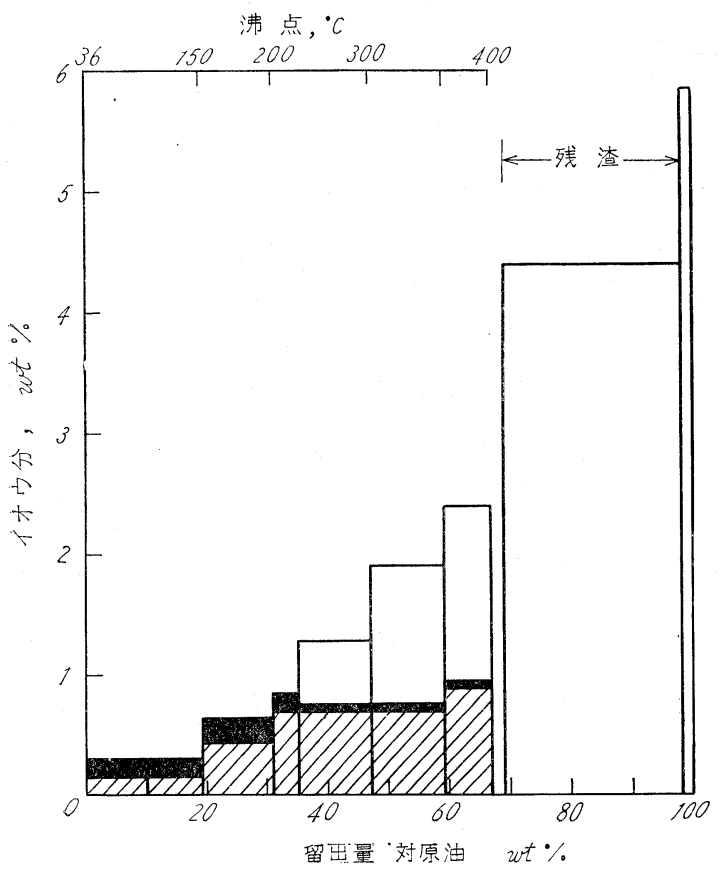

図 3 Wasson 原油のイオウ分布 ${ }^{1)}$

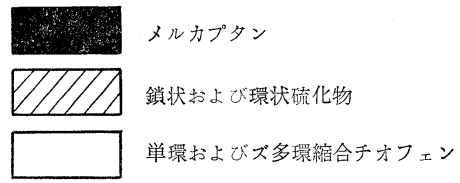

* 硫化水素㔚よびメルカプタンを多量に含む原油をサワー原油 Sour Crude と呼ぶことがある。
分では硫化物が多く，高沸点重質留分ではアルキルチオ フェンおよびその縮合多環誘導体がほとんどであると考 えられる。

ソビエト産の原油とその各留分のイオウ化合物のタイ プ別分析結果については, 昨年の第 7 回世界石油会議の パネルディスカッション “The Non-hydrocarbon Constituents of Petroleum” 中の R.D. Obolentsev の論文 に詳しい9。

わが国においても中東産原油のガソリン，灯油等の軽 質留分のイオウ化合物のタイプ別分析について土屋ら ${ }^{10)}$ 安井ら ${ }^{11)}$ ，古賀ら ${ }^{12)}$ の報告がある。

3. イオウ化合物の個別同定 単なるタイプ別分析 にとどまらず，石油中のイオウ化合物を単離, 同定, 定量 し，さらにその物性を測定する試みがある。その蓠矮は 1948 年に出発した API* とUS Bureau of Mines の共 同研究，Research Project 48,であった。このプロジェ クトは北米産原油 3 種とイラン産 Agha Jari 原油につ いて後述するように合計 144 種のイオウ化合物を同定 し1)，その所期の目標を達成した。引き続いて，沸点 $250^{\circ} \mathrm{C}$ 以上の重質留分のイオウ化合物の解明を目指し て，新たな Research Project 60 が発足している ${ }^{13}$ )。

ソビエトにおいても，ウラル・ボルガ地域における高 イオウ原油の急速な開発に伴ない，石油中のイオウ，窒 素等の有機化合物の分析，その性状の測定，利用の研究 等の重要性が指摘され，1955年にソビエト科学アカデミ 一の Bashikir Branch の化学部門を中心として第 1 回 の会議が開催されて以来, 大学, 研究所等との共同研究 計画が推進されつつある ${ }^{3,4,9)}$ 。

以下のほか, 米, 英, 仏等の石油会社の研究所におい ても活発な研究が行なわれており, その最近の成果は先 にも述べた第 7 回世界石油会議の PD 23 に発表されて いる。

i. イオウ化合物の単離, 同定の手法 紙数の制約も あって詳細は割愛するが，イオウ化合物の分離，同定の 手法について簡単に記しておく。成分分離の常法として 物理的ならびに化学的接近法がある。

物理的方法としては蒸留, 吸着, 液熱拡散等が適用さ

* American Petroleum Institute 
れる。蒸留操作において重要な点は，とくに高分子量の イオウ化合物のうちのある種のものは必ずしも熱的に安 定ではなく，如何にして自然のままのイオウ化合物を入 手するかである。このため蒸留装置に種々の工夫がなさ れ, 分子蒸留も行なわれている。吸着剂としてはシリカ ゲル，アルミナゲルなどが単独ないし組合わせて使用さ れ, 前者は飽和炭化水素と（イオウ化合物十芳香族）を 後者はイオウ化合物と芳香族を, それぞれ分離するのに 有用である。液熱拡散法は非常に純粋なイオウ化合物が 得られる反面，その収率が低い欠点がある ${ }^{14)} 。$

化学的方法は各種イオウ化合物に特有の化学反応性を 利用して抽出, 分離を行なうものである。メルカプタン はその酸性を利用してアルカリ水溶液を用いて抽出が可 能であるが，メルカプタンの分子量が大きくなるにした がって抽出効率が低下するので, イソ酪酸ポタシウムな どの溶解促進剤を加えることが行なわれる。また無水工 チレンジアミンに $1 N$ のソジウムアミノエトキサイド $\left(\mathrm{H}_{2} \mathrm{NC}_{2} \mathrm{H}_{4} \mathrm{ONa}\right)$ を加えた溶剤により効果的にメルカプ タンの抽出が可能であるという提案もある15)。硫化物の 抽出には各種水銀塩による付加化合物生成反応が利用さ れる ${ }^{16 \sim 18)}$ 。アルキル・アリール硫化物の抽出には $p$-卜 ルエンスルフォン酸メチルによる次の反応が利用され $ろ^{199}$ 。

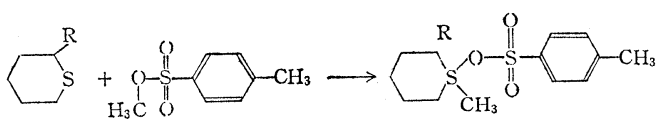

また $-78^{\circ} \mathrm{C}$ の低温下で硫化物のブタンあるいはペン タン溶液に $\mathrm{HI}, \mathrm{HCl}$ 等のハロゲン化水素を通じ固形付 加物を形成せしめて分離する方法もある19)。ベンゾチオ

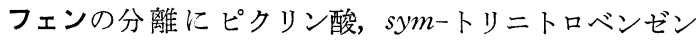
等を利用する提案もなされている ${ }^{20,21)}$ 。

同定の手法としては，もっとも古典的かつ正統的なも のとして, 単離されたイオウ化合物の物性值を測定し, 別途に合成された純粋な標品のそれと比較する方法があ る。実際, 前述の Research Project 48 と併行して Research Projet $48 \mathrm{~B}$ が推進され, 約 40 種の純イオウ 化合物が合成され頒布されている2)。しかし各種の分光 学的分析法の進歩とガスクロマトグラフィーの普及によ って, 上の古典的方法の必然性は低下し, 研究の進展速 度は飛躍的に向上した。この進展に大きな貢献をしたも のとして, 赤外線吸収スペクトル, 紫外線吸収スペクト ル, 質量分析, 核磁気共鳴スペクトル等の名はあげるま でもないであろう。

ここは特記すべきと思われるのは，イオウ化合物（窒
素あるいは酸素化合物にも適用し得る）を水 素化分解 し，生成する炭化水素の構造を同定することにより，も とのイオウ化合物の構造を決定する方法である ${ }^{4,22) 。 こ ~}$ れを GLC, IR, 質量“分析と組合わせることにより非常 な威力が発揮される。また最近, GLC の検出器として イオウ化合物のみを検出し得る(炭化水素は感知しない) 新工夫がなされ，とくに低沸点の石油留分の分析に供試 されて成功を収めている ${ }^{23)}$ 。

ii. 同定されたイオウ化合物 表 3 は RP 48 によっ て同定された有機イオウ化合物の数をタイプ別に一覧表 としたものである。分析対象として選ばれた 4 種の原 油のらち, 最も徹底的に研究されたのはテキ少産の Wasson 原油であり，大多数のイオウ化合物が Wasson 原油中に発見されている。以下に各タイプ別に同定され

表 3 US Bureau of Mines-API RP 48 で同定さ れたイオウ化合物 ${ }^{13}$

\begin{tabular}{|c|c|c|c|c|c|}
\hline 油 & $\begin{array}{l}\text { Wasson } \\
\text { テキサス }\end{array}$ & $\begin{array}{l}\text { Wilmi- } \\
\text { ngton } \\
\text { カリフォ } \\
\text { ルニャ }\end{array}$ & $\begin{array}{c}\text { Agha } \\
\text { Jari } \\
\text { イラン }\end{array}$ & \begin{tabular}{|c|} 
Deep \\
River \\
ミシガン
\end{tabular} & 合計 \\
\hline \multicolumn{6}{|l|}{ メルカプタン } \\
\hline 鎖状 & 39 & & 6 & & 45 \\
\hline 脂環 & 7 & & & & 7 \\
\hline 芳香族 & $1 *$ & & & & 1 \\
\hline \multicolumn{6}{|l|}{ 硫化物 } \\
\hline 鎖状 & 38 & & 5 & & 43 \\
\hline 鋇状一脂環 & 5 & & & & 5 \\
\hline 脂環 & 21 & 14 & & & 35 \\
\hline 二硫化物 & $1^{*}$ & & & 3 & 4 \\
\hline チオフェン類 & & 11 & & & 11 \\
\hline ベンゾチオフェン類 & 13 & & & & 13 \\
\hline 類 & 2 & & & & 2 \\
\hline 計 & 127 & 25 & 11 & 3 & $166^{* *}$ \\
\hline
\end{tabular}

たイオウ化合物を, 留分別に, 表 4, 5, 6 亿示す ${ }^{13) * * * 。 ~}$ ただしこれらのイオウ化合物は分析対象となったす心゙ ての原油洪通して見出されたものとは限らない。

表 4 亿見られると礼り, $100^{\circ} \mathrm{C}$ 以下の留分について は，およそ考えられる構造のイオウ化合物はすべて含ま れているといってよい。ただし 3 員環，4 員環の不安定 な硫化物は例外である。表 5 亿ついてもほぼ上と同様の ことがいえる。表 5 において興味深いのは，未だ確定的 ではないが，二硫化物の存在が認められた点である。以 前は二硫化物は，油層の非還元性雾囲気のために，原油 中には存在しないと考えられていたのであるが，この発

****原報には沸点 $150 \sim 250^{\circ} \mathrm{C}$ のイオウ化合物 52 種が表示されている が割愛した。 
変 4 沸点約 $100^{\circ} \mathrm{C}$ 以下の石油留分中のイオウ化合物

\begin{tabular}{|c|c|c|}
\hline メルカプタン & 硫 化 物 & チオフェン \\
\hline$\left(\mathrm{H}_{2} \mathrm{~S}\right)$ & $\mathrm{CH}_{3} \mathrm{SCH}_{3}$ & 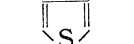 \\
\hline $\mathrm{CH}_{3} \mathrm{SH}$ & $\begin{array}{c}\mathrm{CH}_{3} \mathrm{CH}_{2} \mathrm{SCH}_{3} \\
\mathrm{CH}_{3}\end{array}$ & \\
\hline $\mathrm{C}_{2} \mathrm{H}_{5} \mathrm{SH}$ & $\mathrm{CH}_{3} \stackrel{\stackrel{1}{\mathrm{C}} \mathrm{HSCH}}{3}$ & \\
\hline $\mathrm{CH}_{3}$ & & \\
\hline $\mathrm{CHSH}$ & $\mathrm{CH}_{8} \mathrm{CH}_{2} \mathrm{SCH}_{2} \mathrm{CH}_{3}$ & \\
\hline $\mathrm{CH}_{3}$ & & \\
\hline $\mathrm{CH}_{3}$ & \multirow{3}{*}{$\begin{array}{c}\mathrm{CH}_{3} \\
\mathrm{CH}_{3}-\mathrm{I}_{\mathrm{C}}^{\mathrm{C} C \mathrm{SCH}_{3}} \\
\mathrm{CH}_{3}\end{array}$} & \\
\hline $\mathrm{CH}_{3}-\mathrm{C}-\mathrm{SH}$ & & \\
\hline $\mathrm{CH}_{3}$ & & \\
\hline $\mathrm{CH}_{3} \mathrm{CH}_{2} \mathrm{CH}_{2} \mathrm{SH}$ & & \\
\hline $\mathrm{CH}_{3}$ & & \\
\hline $\mathrm{CH}_{3} \mathrm{CH}_{2} \mathrm{CHSH}$ & & \\
\hline $\begin{array}{c}\mathrm{CH}_{3} \\
\mathrm{CH}_{3} \mathrm{CHCH}_{2} \mathrm{SH}\end{array}$ & & \\
\hline $\mathrm{CH}_{3} \mathrm{CH}_{2} \mathrm{CH}_{2} \mathrm{CH}_{2} \mathrm{SH}$ & & \\
\hline $\mathrm{CH}_{3}$ & & \\
\hline $\mathrm{CH}_{3} \mathrm{CH}_{2} \mathrm{C}-\mathrm{SH}$ & & \\
\hline $\mathrm{CH}_{3}$ & & \\
\hline
\end{tabular}

表 6 沸点約 250 以上の石油留分中のイオウ化合物

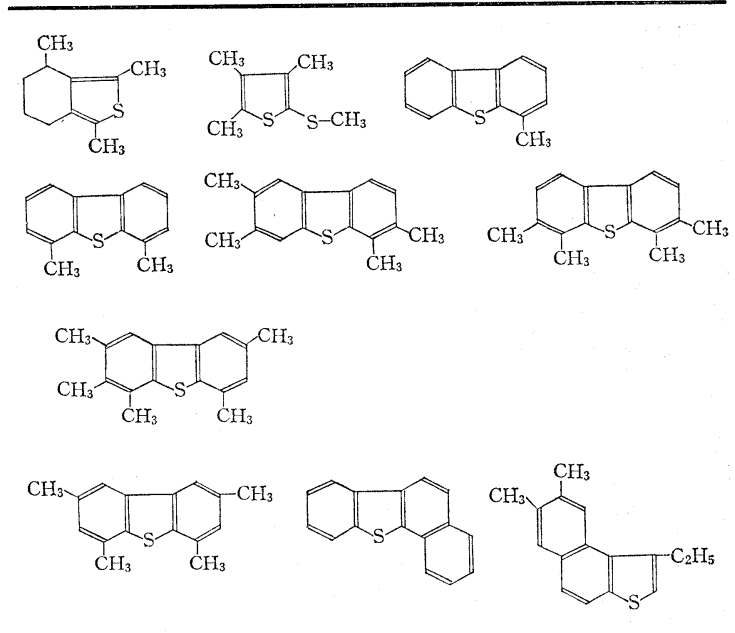

見により油層への大気の浸入の可能性が示唆されてい る*。

沸点 150 ～ $250^{\circ} \mathrm{C}$ の留分にはベンゾチオフェン類，チ アインダン類が発見されてい

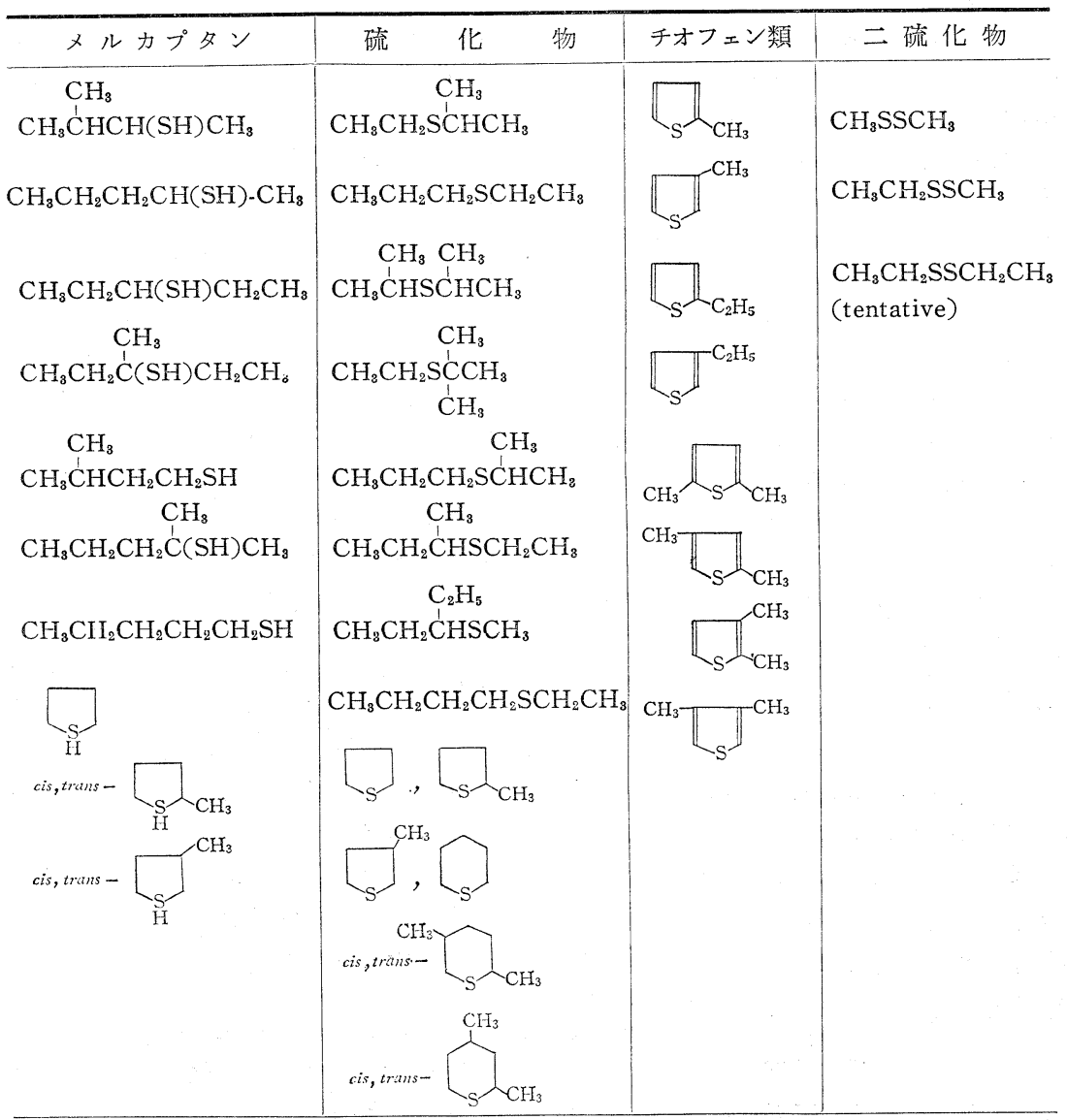

る。これらの表から直接いえ ることではないが，メルカプ タンや硫化物の含有量は重質 留分では減少し，代って環状 硫化物，縮合多環チオフェン 誘導体の含有量が増加するこ とが推測される。沸点 $250^{\circ} \mathrm{C}$ 以上の留分のイオウ化合物に ついては，表6に見るとおり 同定数は未だ 僅少であり， 今後の研究の進展が期待され る。表 7 は RP 48 以外の研 究者によって同定されたイオ ウ化合物の総括である ${ }^{1)} 。$

以上の表に法元素イオウが 示されていない。元素イオウ は “自然の”原油中には含ま れていないといらのが通説で あった。原油中の硫化水素 が，採油されたのち大気中の 酸素儿触れて酸化され，元素 イオウを生成するものと考え

* メルカプタンは容易に酸化されて 二硫化物を生成する。また二硫化 物は熱的に不安定で容易に分解す る。 
表 7 RP 48 以外に同定されたイオウ化合物

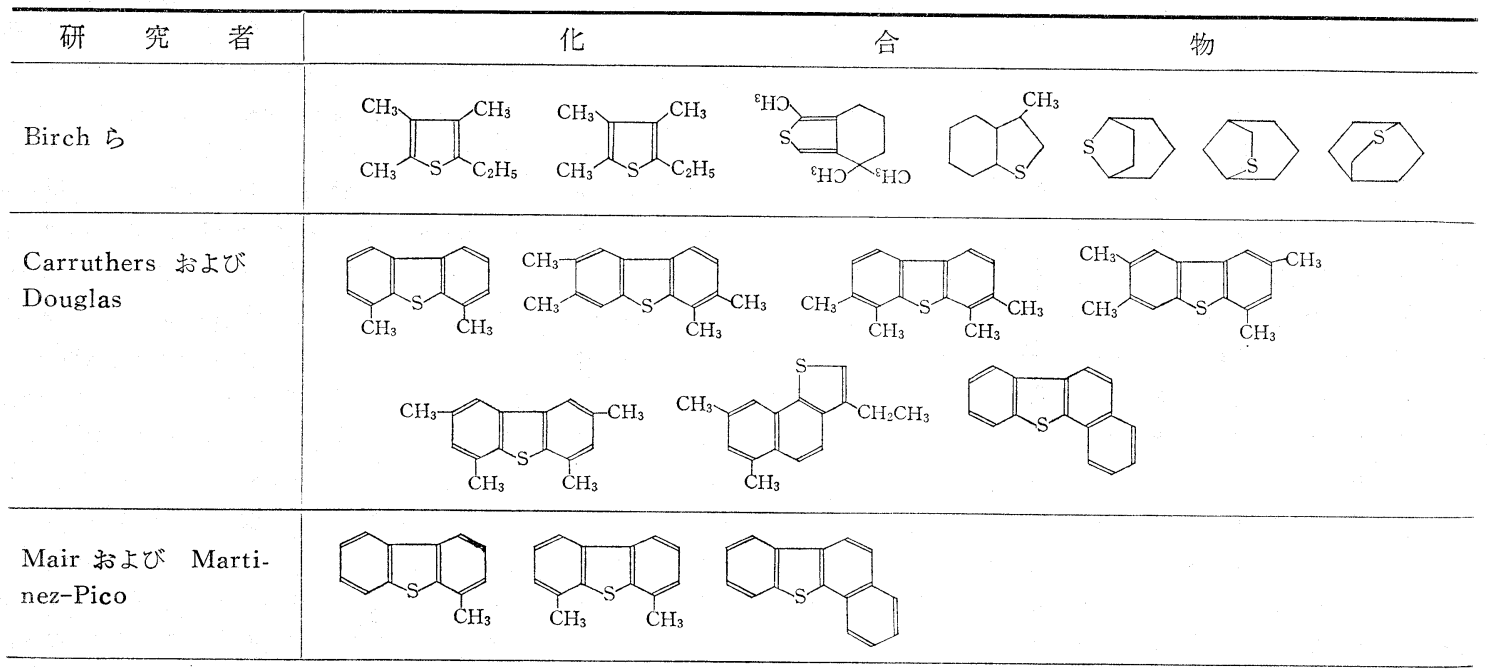

られてきた。しかし，Drushel ら ${ }^{24)}$ および Eccleston $ら^{25}$ は十分な注意のもとに自然のままの原油試料を採 取，分析して West Texas 原油中に元素イオウが存在 することを報告している。元素イオウは各種の炭化水素 と $150 \sim 175^{\circ} \mathrm{C}$ においてかなり容易に反応し, 硫化水素 や有機イオウ化合物を生成する事実と照して，原油中の 元素イオウの存在は石油生成の過程において $150^{\circ} \mathrm{C}$ 以上 の高温にさらされたことのないことを示唆し，石油の起 源を研究するらえで一つの手䀣りを与えるものであろ ら。

石油中のイオウ化合物の成因については，石油炭化水 素自身の起源である有機物中のイオウ化合物の化学変化 によるとする考えから，炭化水素とイオウもしくは硫化 水素との化学反応により二次的に生成するというものま で，種々の推測がなされているが，この議論は本稿の範 囲を越えるので参考文献を参照されたい $7,28,30) 。$

iii. 石油中のイオウ化合物の利 用について 石油中 のイオウ化合物は，これまでのところ，石油精製工程に おいては装置の腐蝕や触媒の被毒の原因となり，また石 油製品の品質についてみれば，たとえばガソリンにおい て臭気，加鉛効果の阻害，安定性の低下などの悪影響を およぼす。潤滑油では natural inhibitor として酸化防 止作用や極圧潤滑性の向上等の面でプラスの効果もない ではないが，それとても，高級潤滑油製造の立場からは むしろ無益であり水素化精製が行なわれる䞤勢である。

しかし，石油中のイオウ化合物を単に敵視するだけで なく，積極的な利用の途はないだろうか。禍を転じて福 となすことはできないだろうか。石油消費量の飛躍的な
伸長とともに，石油中のイオウ化合物の集積量はこれを 化学的資源とみなすに不足はない時代である。しかも， すでに述べたとおり，多年の研究の結果石油中のイオウ 化合物の組成や構造もかなり明らかになって来た。工業 的に実用可能な効率的, 経済的なイオウ化合物の分離法 が確立され，またイオウ化合物の用途が開発されるなら ば，石油精製と石油化学の有機的結合を生み，この意味 で一石二鳥の効果が期待される。以上はいうは易く行な らは難しである。さしあたりの課題としては，水素化脱 硫法によって副生する元素イオウの有効利用の研究が重 要であろう。

石油中のイオウ化合物の利用面として考えられるもの の 2,3 の例を次に示す。詳細な議論は筆者の能力をこえ るので，むしろ読者諸賢の自由な発想を期待したい。

メルカプタン：着臭剤，溶剤，酸化防止剤，重合調整 剤,メチオニン

硫化物: 着臭剤, 潤滑油用酸化防止剤, スルフォン, スルフォキサィドの合成原料

チオフェン: 樹脂, 染料, 医薬, 溶剂 有機イオウ化合物の性質，合成法，用途等については Reid の集大成がある ${ }^{31)}$ 。石油から得られるイオウ化合 物とその利用については吉村 ${ }^{32}$ の解説を参照されたい。

$(\supset つ<)$

(昭和 43 年 5 月 31 日受理)

単行本

$$
\text { 文献 }
$$

1) Hydrocarbon Analysis, A Symposium Presented at the Meeting of Committee D-2 on Petroleum Products and Lubricants of the ASTM, Houst- 
on, Tex., Jan. 22-23, 1965, ASTM Special Publication No. 389, ASTM, Philadelphia, USA (1965)

2) Howard D. Hartough, Chemistry of Sulfur Compounds in Petroleum, Advances in Petroleum Chemistry and Reflning, Vol. III, p. 418, Interscience Publishers, Inc. (1960)

3) Chemistry of Organic Sulfur Compounds in Petroleum and Petroleum Products, Proceedings of the 2 nd Scientific Session, Academy of Sciences of USSR, Ufa 1958, Translated from Russian, Israel Program for Scientific Translations Ltd., (1963)

4) S.R. Sergienko, High-Molecular Compounds in Petroleum, Translated from Russian, Israel Program for Scientific Translations, Danier Davey \& Co. Inc. (1965)

\section{㮅誌等}

5) W.F. Faragher, J.C. Morrell, G.S. Monroe, Ind. Eng. Chem. 191281 (1927)

6) J.S. Ball, U.S. Bureau of Mines, Rept. Invest. 3591 (1941)

7) C.J. Thompson, H.J. Coleman, H.T. Rall, H. M. Smith, Anal. Chem. 27175 (1955)

8) J.H. Hale, C.J. Thompson, M.C. Barker, H. M. Smith, J.S. Ball, Anal. Chem. 23287 (1951)

9) R.D. Obolentsev, Proceedings of 7 th World Petroleum Congress, PD 23 (3) Mexico City (1967)

10) 土屋, 橋本, 富永, 石油学会誌 2485 (1959)

11）安井，紀，奈古 ibid. 2492 (1959)

12) 古賀，梶川，川口，ibid. 2488 (1959) ibid. 3 397 (1960)

13) R.A. Dean, E.V. Whitehead, Proceedings of 7 th World Petroleum Congress, PD 23 (7) Mexico City (1967)
14) C.J. Thompson, H.J. Coleman, C.C. Ward, H. T. Rall Anal. Chem. 291601 (1957)

15) R.L. Hopkins, H.M. Smith, Anal. Chem. 26 206 (1954)

16) J.S. Ball, Oil \& Gas J. April 7, 109 (1945)

17) S.F. Birch, D.T. McAllan, J. Inst. Petrol. 37 443 (1951)

18) S.F. Birch, R.A. Deau, R.L. Denyer, Ind. Eng. Chem. 47240 (1955)

19) R.L. Hopkins, H.J. Coleman, C.J. Thompson, H.T. Rall, Report of Investigations 6458, US Bureau of Mines (1964)

20) J.W. Cook, W. Carruthers, J.F. Miller, Anal. Chem. 301271 (1958)

21) H.J. Coleman, C.J. Thompson, R.L. Hopkins, N.G. Foster, M.L. Whisman, D.M. Richardson, Chem. Eng. Data 6464 (1961)

22) C.J. Thompson, H.J. Coleman, R.L. Hopkins, H.T. Rall, Proceedings of 7 th World Petroleum Congress, PD23 (2), Mexico City (1967)

23) R.L. Martin, and J.A.Grant, Div. Pet. Chem. Inc. Am. Chem. Soc., Preprints, 10(2), C 5-C 15, C 17-C 29 (1965)

24) H.V. Drushel, J.F. Miller, W. Hubis, R.O. Clark, Anal. Chim. Acta 15394 (1956)

25) B.H. Ecclestor, M. Morrison, H.M. Smith, Anal. Chem. 241745 (1952)

26) I.A. Breger, Organic Geochemistry, Pergamon Press Ltd., (1963)

27) U. Colombo, G.O. Hobson, Advances in Organic Geochemistry, Pergamon Press Ltd. (1964)

28) 三土, 石油学会 82,8 (1965)

29) E. Emmett Reid, "Organic Chemistry of Bivalent Sulfur" Vol. I VI, Chemical Publishing Co., New York (1957 66)

30) 吉村, 石油学会誌 8272 (1965) 